\title{
A new method for measuring the body density of obese adults
}

\author{
By J. S. GARROW, SUSAN STALLEY, R. DIETHELM, Ph. PITTET, \\ R. HESP AND D. HALLIDAY \\ Medical Research Council, Clinical Research Centre, \\ Watford Road, Harrow, Middlesex $\mathrm{HAI}_{3} U J$
}

(Received 2 February 1979-Accepted 4 April 1979)

\begin{abstract}
1. A new apparatus is described with which it is possible to measure the volume (and hence density) of obese patients without requiring them to immerse totally in water. Replicate measurements of subjects with 6,23 and $38 \mathrm{~kg}$ body fat had a standard deviation not greater than $0.3 \mathrm{~kg}$ fat.

2. In nineteen obese women body fat was measured by density, total body water, and total body potassium at the beginning, and again at the end, of a period of 3-4 weeks on a reducing diet, during which they lost 5.43 (SD I. 83) kg in weight. The composition of weight loss was also estimated both by energy balance and nitrogen balance during the interval between the two measurements of body composition.

3. The estimates of fat content of the nineteen women at the start of the balance period were 45.63 (SD 14.50) $\mathrm{kg}$ by density, 48.07 (SD 13.88) $\mathrm{kg}$ by $\mathrm{K}$ and 47.09 (SD 13.85) kg by water. The correlation coefficient between the density and $K$ estimate was 0.949 , and for the density and water estimate it was 0.971 .

4. It is concluded that measurement of density by the new method provides a convenient method for estimating body fatness, and change in fat content, which compares favourably with estimates based on total body water or total body $\mathrm{K}$. However, these methods cannot be used to provide an accurate estimate of the composition of a small weight loss in an individual since deviations up to $4 \mathrm{~kg}$ fat occur between fat loss based on change in density and those based on the more reliable (but more tedious) energy balance method.
\end{abstract}

Obesity is the commonest nutritional disease in the UK (DHSS/MRC Study Group, 1976), and is characterized by excessive fat stores, and hence excessive weight. Weight loss in an obese patient does not necessarily reflect fat loss, so we need a technique which will enable us to measure the amount of fat in an obese patient as accurately as possible in a manner which is acceptable to the patient. The available techniques have been reviewed in detail elsewhere (Garrow, 1978): briefly their advantages and limitations are as follows. Skinfold thickness is difficult to measure in obese patients, and the table of Durnin \& Womersley (1974) does not cover very fat subjects. Techniques relying on fat-soluble-gas dilution are theoretically attractive (Hytten et al. 1966; Lesser et al. 197I), but unacceptable to patients, since it is necessary to breathe the gas mixture during a long equilibration period. If the assumption is made that the fat-free body has a constant amount of water or potassium, then a measurement of total body water by deuterium dilution (Halliday \& Miller, 1977) or of total body $\mathrm{K}$ by whole body counting of ${ }^{40} \mathrm{~K}$ (Smith et al. 1979) will yield an estimate of fat-free mass, and hence of body fat. However, the underlying assumption is not true (Womersley et al. 1976; Wang \& Pierson, 1976; Garrow, 1978), because the fat-free tissues vary in water and $\mathrm{K}$ content.

The method for measuring body composition which is in principle most reliable is densitometry. Behnke et al. (1942) showed that it was possible to distinguish between obese men and muscular men by determining the ratio, weight: volume of the sum of all the body tissues. The density of individual tissues has been measured (Allen et al. I959); human fat has a density of $0.900 \times 10^{3} \mathrm{~kg} / \mathrm{m}^{3}$, and the average density of lean tissue is approximately $\mathrm{I} \cdot \mathrm{I} 00 \times 10^{3} \mathrm{~kg} / \mathrm{m}^{3}$ (Keys \& Brozek, 1953). Lean tissue is a mixture of water, protein and mineral, which have densities, at body temperature of approximately $0.993, I \cdot 34$ and 
$3.00 \times 10^{3} \mathrm{~kg} / \mathrm{m}^{3}$ respectively. Obviously the density of the fat-free body depends on the proportions in which these components occur.

It is fairly easy to measure the volume of a subject who is willing to submerge calmly and completely in water, either from the volume of water displaced, or from the loss of weight as described by Archimedes. However, many obese patients are unable to tolerate total submersion. Irsigler et al. (1975) overcame this difficulty by using a device in which the subject is immersed only to neck level, and the head is covered by a clear-plastic lid. The air space around the head is measured by observing the volume change which is necessary to cause a given change in pressure. Our apparatus, which is a development of this principle, will be described, and results will be compared with those obtained from measurements of energy balance, nitrogen balance, total body water and total body $\mathrm{K}$.

\section{EXPERIMENTAL}

\section{Apparatus}

This is illustrated in Fig. I. A steel cylinder $\mathrm{I} \cdot 5 \mathrm{I} \mathrm{m}$ deep and $0.60 \mathrm{~m}$ internal diameter is recessed into the floor of the laboratory so that only $0.3 \mathrm{~m}$ projects above floor level. The cylinder below floor level is lagged to prevent excessive heat loss from the water, and the temperature of the wall of the tank is monitored by a thermocouple thermometer. To facilitate drainage a tap is fitted at the bottom of the tank, and the waste pipe is connected to a drain in the room below.

A clear-Perspex tube is connected to the side of the tank so the water level is visible at all times.

A clear-Perspex lid is coupled to the tank by a pair of machined flat aluminium rings sealed to the lid, and to the top of the tank respectively. A locating pin ensures that the rings register exactly, and a rubber ' $O$ ' ring, mounted in a groove in the upper ring, provides an air-tight seal. The lid is divided into an upper reference chamber and a lower compartment for the subject's head. Pressure fluctuations in these two compartments are produced by a reciprocating piston with a displacement of $0.25 \mathrm{l}$, driven by a motor at a frequency of I Hz. Each of the compartments is connected to atmosphere by a small leak, and the pressure in each is monitored by a transducer with an output of I $v$ for $500 \mathrm{mmWG}$ pressure change (type $\mathrm{FCO}_{40}$ o Furness Controls). The tube connecting the transducer to the lower compartment is closed with a soft rubber balloon. A microphone-loud speaker mounted in the lid provides communication between the subject and operator.

A block diagram of the electronic circuits is shown in Fig. 2. The output from the two transducers is amplified, rectified, and fed through a low-pass filter to accept the I $\mathrm{Hz}$ signal from the pump. These two signals, $x$ from the reference chamber and $y$ from the subject compartment, pass to a divider, from which the output is proportional to $x / y$. This is compared to a reference voltage (A), derived from a zener diode circuit. The difference between the output of the divider and the reference source (see Fig. I) is fed to a recorder.

\section{Operating procedure}

The plethysmograph is filled with water at approximately $34^{\circ}$. The inner surface of the lid is wiped with detergent so it is not obscured by condensation, and the lid is placed on the plethysmograph tank. The pump is switched on, and the water level is adjusted to give a zero reading on the recorder.

The subject is weighed on a balance which also carries a large water tank. The subject then comes off the balance, the lid is lifted from the plethysmograph, and water is transferred 


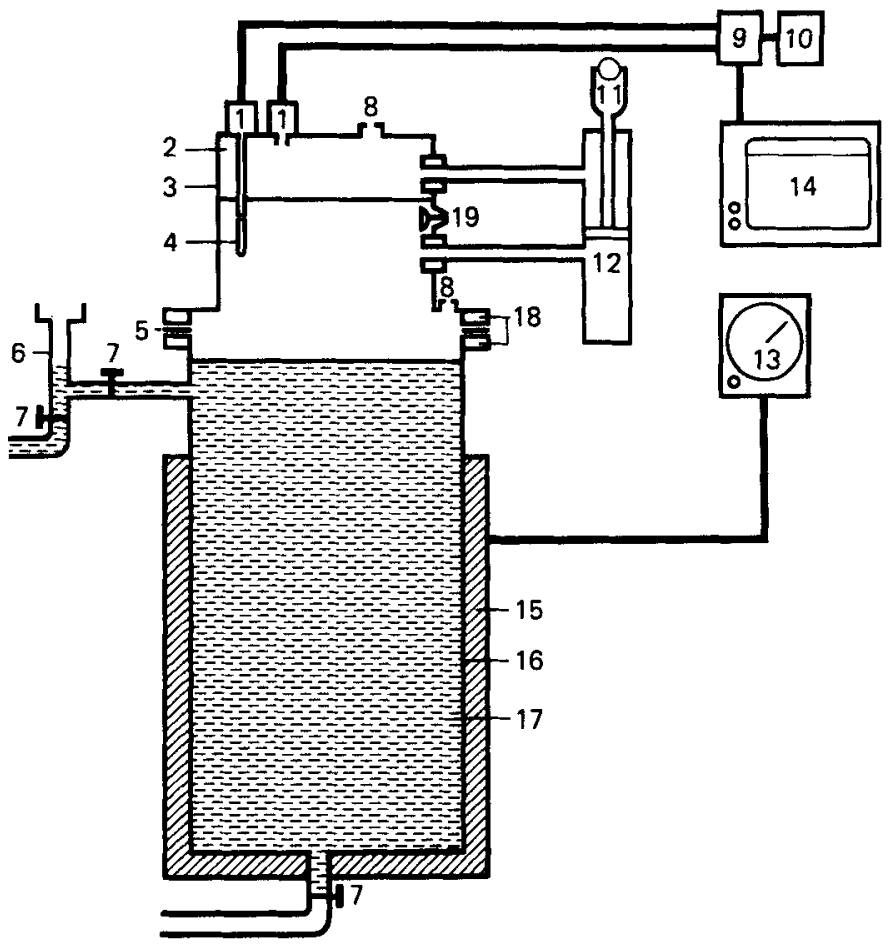

Fig. I. Schematic diagram of the plethysmograph apparatus. Pressure transducers (I) detect pressure changes in an upper reference chamber (2) and the lower chamber (4) of a clear plastic lid (3) which is placed over the subject's head. The lid is coupled to the plethysmograph tank (I6) by flanges (18) sealed with a rubber gasket (5). The water level in the tank is shown in a side tube (6) and controlled by taps (7). The pressure in the reference chamber and lower chamber is kept close to atmospheric by small leaks (8). The pressure fluctuations are produced by a pump (12) driven by a motor (II). The signal from the transducers is compared in a unit (9) of which the circuit is shown in Fig. 2. The output is compared with a reference voltage (10) and the difference signal is recorded on a pen recorder (14). The temperature of the water in the plethysmograph (17) is measured with an electrical thermometer (13). The tank below floor level is lagged with fibreglass (I 5). The microphone-loudspeaker (19) allows the subject and operator to communicate.

from the plethysmograph to the water tank until the same reading is obtained: thus the subject's weight of water has been removed from the plethysmograph. In the case of very obese or very thin subjects it may be necessary to remove more or less water in order to obtain near-balance conditions when the subject is in the plethysmograph (see Calculation of results).

The subject is now lowered into the plethysmograph, the lid is replaced, and the pump is switched on again. The subject breathes normally, since air in the lungs and gut are automatically measured (see Calibration). After a period of $3 \mathrm{~min}$ the lid is removed to supply the subject with fresh air, then replaced and another measurement is done. If agreement between the first two runs is poor a third 3 min test is done. The total time involved for the subject is about $20 \mathrm{~min}$. The total volume in the lid is about 101 , and there is no appreciable increase in carbon dioxide concentration during the $3 \mathrm{~min}$ test period. 


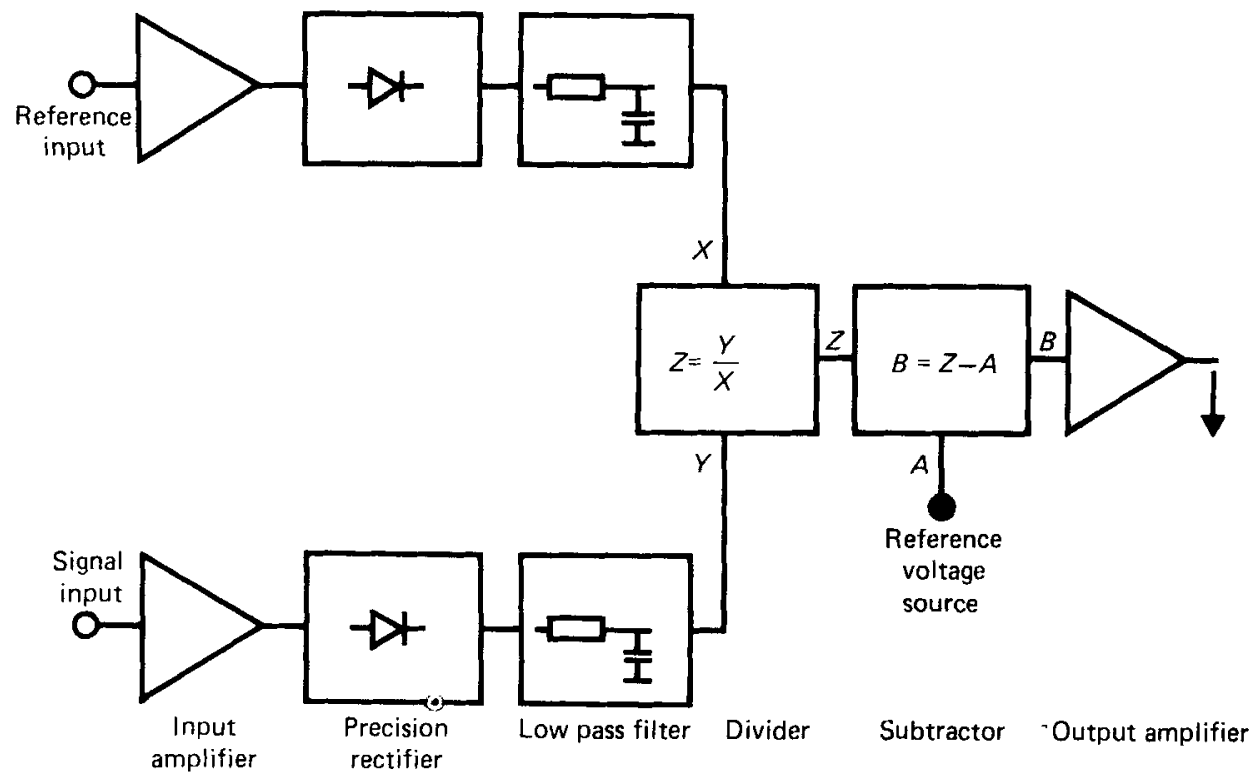

Fig. 2. Block diagram of electronic unit of the plethysmograph apparatus shown in Fig. 1.

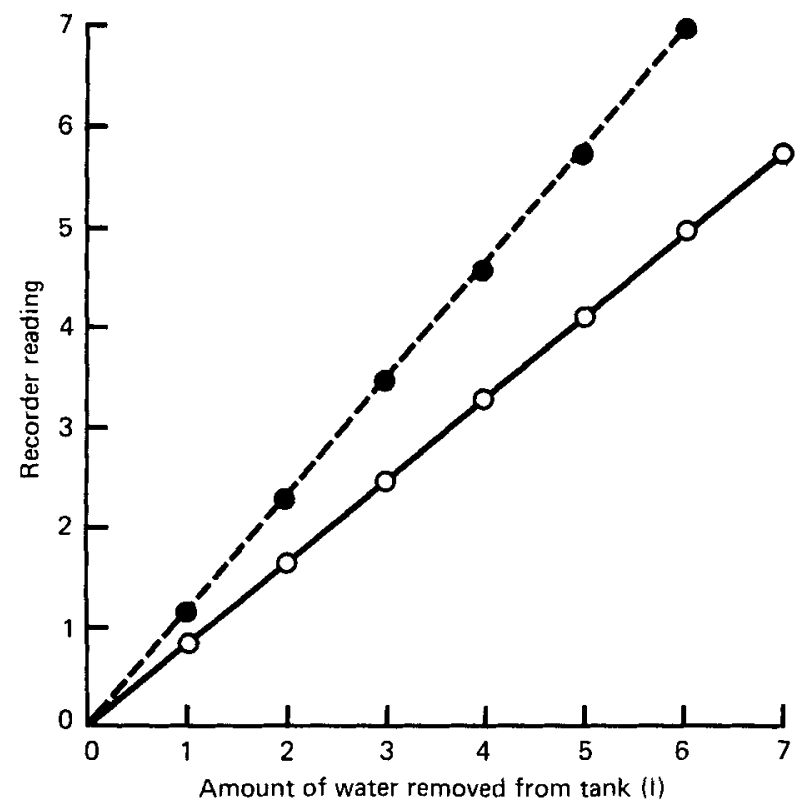

Fig. 3. Calibration curves relating change of water volume in the plethysmograph to the reading on the recorder (see Fig. I). $(\mathrm{O}-\mathrm{O})$, The relationship when the air behaves adiabatically; (- - ), the relationship when isothermal conditions are produced. The latter curve should be used to estimate the volume of subjects. 


\section{Calibration}

In an ideal gas at constant temperature there is a simple reciprocal relationship between pressure and volume. Fig. 3 shows the relationship of recorder reading to the volume of water in the tank. The zero point is obtained with the tank full, and successive points by removing water in 1.01 steps. However this is not the appropriate calibration curve to use when estimating the volume of air round a subject in the tank, since the air in the lungs and gut of the subject behaves isothermally during the cycle of compression and expansion, whereas the air which is not in close proximity to some solid object undergoes adiabatic expansion and compression. During the adiabatic compression phase the air becomes hotter, so the increase in pressure is greater than the simple isothermal equation would predict. The practical effect of this is shown by the continuous line in Fig. 3 which is the calibration curve obtained when, after removing each I 1 water a I 1 block of foam plastic is inserted, so that the extra $\mathrm{I} l$ of air now behaves in an isothermal fashion. This has the effect of increasing the recorder reading by approximately $30 \%$.

\section{Calculation of results}

The density of water at $34^{\circ}$ is 0.993 , and the difference between the volume of the subject, and the volume of an equal weight of water $(x)$, is displayed on the recorder. In the case of very obese patients, who have a density less than that of water, it is necessary to remove some water $(y)$ to obtain a result which is on the scale of the recorder.

The volume $(V)$ of a subject of weight $W$ is therefore

$$
\frac{W}{0.993}-x+y, \text { and density }(d) \text { is } \frac{W}{V} \text {. }
$$

The percentage of fat in the body weight for weight is calculated from the formula:

$$
\text { Fat }(\%)=450\left(\frac{1 \cdot I}{d}-1\right) . \quad(\text { Siri, 196I. })
$$

\section{RESULTS}

To determine the reproducibility of the method the density of three subjects was determined four times on a single day. The entire cycle of 'zeroing' the plethysmograph, weighing the subject, pumping out the equivalent weight of water, and then measuring the volume of the subject was performed each time, and the results are shown in Table $\mathrm{I}$. In the three subjects, who ranged in estimated fat content from 90 to $460 \mathrm{~g} / \mathrm{kg}$ body-weight, the standard deviation on the four replicate measurements did not exceed $0.3 \mathrm{~kg}$ fat. The technique was then applied to patients, using a protocol approved by the Northwick Park Hospital Ethical Committee.

Estimates of fat content in nineteen women in a metabolic ward for treatment of obesity were made by three methods: density was measured as described previously, the relative amount of fat ( $\mathrm{g} / \mathrm{kg}$ body-weight) and absolute fat content was calculated. Secondly, total body $\mathrm{K}$ was measured by whole body counting of the $1.46 \mathrm{MeV}$ gamma rays from ${ }^{40} \mathrm{~K}$ (Smith et al. 1979), and on the assumption that the fat-free body contained $60 \mathrm{mmol} \mathrm{K} / \mathrm{kg}$, the fat-free mass was calculated, and hence, by subtraction from body-weight, the fat mass. Finally total body water was measured by deuterium dilution (Halliday \& Miller, 1977), and on the assumption that fat-free mass contained $730 \mathrm{~g}$ water $/ \mathrm{kg}$ the fat-free mass, and hence fat mass were calculated. The results are shown in Table 2. The average fat mass 
Table I. Replicate measurements of fat in three subjects

\begin{tabular}{|c|c|c|c|c|c|}
\hline Subject & Wt (kg) & Volume (l) & Density $(g / l)$ & $\begin{array}{c}\text { Fat }(\mathrm{g} / \mathrm{kg} \\
\text { body-wt) }\end{array}$ & Fat (kg) \\
\hline S.S. & $\begin{array}{l}69.44 \\
69 \cdot 62 \\
69 \cdot 67 \\
69.73\end{array}$ & $\begin{array}{l}67 \cdot 72 \\
67 \cdot 87 \\
67 \cdot 92 \\
67 \cdot 97\end{array}$ & $\begin{array}{l}1.0255 \\
1.0258 \\
1.0254 \\
1.0258\end{array}$ & $\begin{array}{l}32 \cdot 71 \\
32 \cdot 58 \\
32 \cdot 73 \\
32 \cdot 58\end{array}$ & $\begin{array}{l}22 \cdot 71 \\
22 \cdot 68 \\
22 \cdot 80 \\
22 \cdot 72\end{array}$ \\
\hline $\begin{array}{l}\text { Mean } \\
\text { SD }\end{array}$ & & & & $\begin{array}{r}32.63 \\
0.08\end{array}$ & $\begin{array}{r}22.73 \\
0.05\end{array}$ \\
\hline P.P. & $\begin{array}{l}70 \cdot 11 \\
70 \cdot 20 \\
70 \cdot 15 \\
70 \cdot 20\end{array}$ & $\begin{array}{l}65 \cdot 00 \\
65 \cdot 10 \\
65 \cdot 17 \\
65 \cdot 11\end{array}$ & $\begin{array}{l}1.0786 \\
1.0784 \\
1.0765 \\
1.0782\end{array}$ & $\begin{array}{l}8 \cdot 93 \\
9 \cdot 01 \\
9 \cdot 83 \\
9 \cdot 12\end{array}$ & $\begin{array}{l}6 \cdot 26 \\
6 \cdot 33 \\
6.90 \\
6.40\end{array}$ \\
\hline $\begin{array}{l}\text { Mean } \\
\text { SD }\end{array}$ & & & & $\begin{array}{l}9.22 \\
0.41\end{array}$ & $\begin{array}{l}6.47 \\
0.29\end{array}$ \\
\hline F.P. & $\begin{array}{l}82 \cdot 18 \\
82 \cdot 60 \\
86 \cdot 20 \\
82 \cdot 77\end{array}$ & $\begin{array}{l}82 \cdot 40 \\
82 \cdot 61 \\
82 \cdot 77 \\
83 \cdot 06\end{array}$ & $\begin{array}{l}0.9973 \\
0.9970 \\
0.9980 \\
0.9965\end{array}$ & $\begin{array}{l}46 \cdot 35 \\
46 \cdot 48 \\
46 \cdot 00 \\
46 \cdot 72\end{array}$ & $\begin{array}{l}38.09 \\
38.28 \\
38.00 \\
38.67\end{array}$ \\
\hline $\begin{array}{l}\text { Mean } \\
\text { SD }\end{array}$ & & & & $\begin{array}{r}46 \cdot 39 \\
0.30\end{array}$ & $\begin{array}{r}38.26 \\
0.30\end{array}$ \\
\hline
\end{tabular}

calculated from the three methods agrees quite well: $45.63 \mathrm{~kg}$ from density, $48.07 \mathrm{~kg}$ from $\mathrm{K}$ and $47.09 \mathrm{~kg}$ from water measurements. The correlation coefficient between the estimates by density and $\mathrm{K}$ is 0.949 , between density and water is 0.971 , and between $\mathrm{K}$ and water it is 0.978 .

In order to determine which method is the most accurate, it would be necessary to obtain the 'correct' answer for fat mass in each person by a completely reliable method, and thus to determine the error of estimates based on either density, $\mathrm{K}$ or water. The only method which is more accurate is direct chemical analysis, which is clearly not applicable to living patients. An alternative approach is to estimate the change in fat content over a period of a few weeks, and to see if estimates of fat content at the beginning and end of the period correctly reflect this change. The measurements shown in Table 2 were made at the beginning of a period during which these nineteen obese women were in a metabolic ward, with both energy intake and output carefully monitored. The protocol has been more fully described by Garrow $e$ t al. (1978). The energy intake was determined by bomb calorimetry, and precautions were taken to prevent any food reaching the patients other than that which had been analysed. Energy expenditure was measured by both indirect and direct calorimetry. All excreta were collected and analysed by Kjeldahl's method, so it was possible to calculate both energy balance and $\mathrm{N}$ balance over a period of 3-4 weeks. The initial weight, weight loss and energy deficit for each patient is shown in Table 3. On average they lost $5.43 \mathrm{~kg}$, had an energy intake of $63.12 \mathrm{MJ}$ and an energy expenditure of 178.47 MJ, so energy stores must have decreased over the study period by II5.33 MJ. If the weight loss had been pure fat, supplying $37.62 \mathrm{MJ} / \mathrm{kg}$, a loss of $5.43 \mathrm{~kg}$ would represent 204.28 MJ instead of the observed I I5.33 MJ, so obviously some of the weight lost was not fat. If the assumption is made that weight lost was either fat, supplying $37.62 \mathrm{MJ} / \mathrm{kg}$, or lean tissue supplying $4 \cdot 18 \mathrm{MJ} / \mathrm{kg}$, then from the weight loss and energy deficit in each patient, the contribution of fat and lean tissue to the weight loss can be calculated.

From chemical analysis of human cadavers, the $\mathbf{N}$ content of the fat-free body is approximately $3 \mathrm{~g} \mathrm{~N} / \mathrm{kg}$ (Garrow, 1978 ). We may therefore assume that $\mathrm{N}$ balance on the 
Table 2. Total body fat estimated by measurement of potassium, density or water* in obese women

\begin{tabular}{|c|c|c|c|c|c|c|c|}
\hline \multirow{2}{*}{$\begin{array}{c}\text { Patient } \\
\text { no. }\end{array}$} & \multirow[t]{2}{*}{ Wt (kg) } & \multicolumn{2}{|c|}{ Density } & \multicolumn{2}{|c|}{ Potassium } & \multicolumn{2}{|c|}{ Water } \\
\hline & & $\underset{\text { body-wt }}{\mathrm{g} / \mathrm{kg}}$ & kg & $\begin{array}{c}\mathrm{g} / \mathrm{kg} \\
\text { body-wt }\end{array}$ & kg & $\begin{array}{c}\mathrm{g} / \mathrm{kg} \\
\text { body-wt }\end{array}$ & $\mathrm{kg}$ \\
\hline I & $60 \cdot 24$ & $28 \cdot 57$ & $17 \cdot 21$ & $42 \cdot 56$ & $25 \cdot 64$ & $39 \cdot 79$ & 23.97 \\
\hline 2 & 84.40 & 44.06 & $37 \cdot 19$ & 46.59 & $39 \cdot 32$ & $49 \cdot 62$ & $4 I \cdot 88$ \\
\hline 3 & $77 \cdot 26$ & 43.77 & $33.8 I$ & 49.69 & $38 \cdot 39$ & $49 \cdot 42$ & $38 \cdot 18$ \\
\hline 4 & $78 \cdot 74$ & $41 \cdot 71$ & $32 \cdot 84$ & $49 \cdot 23$ & $38 \cdot 76$ & $41 \cdot 74$ & $32 \cdot 87$ \\
\hline 5 & 90.73 & $40 \cdot 73$ & $36 \cdot 95$ & $42 \cdot 85$ & 38.88 & 44.91 & $40 \cdot 75$ \\
\hline 6 & 88.66 & $46 \cdot 20$ & 40.96 & 43.74 & $38 \cdot 78$ & $4 I \cdot 74$ & 37.01 \\
\hline 7 & $101 \cdot 34$ & 43.96 & 64.55 & 50.21 & 50.88 & $49 \cdot 12$ & $49 \cdot 78$ \\
\hline 8 & 82.01 & $42 \cdot 03$ & $34 \cdot 49$ & $41 \cdot 69$ & 34.19 & $43 \cdot 37$ & 35.57 \\
\hline 9 & $98 \cdot 50$ & 45.93 & $45 \cdot 24$ & 45.69 & 45.00 & $44 \cdot 14$ & $43 \cdot 48$ \\
\hline I0 & 122.85 & $49 \cdot 98$ & $61 \cdot 40$ & $59 \cdot 16$ & $72 \cdot 68$ & $54 \cdot 38$ & $66 \cdot 81$ \\
\hline II & 94.93 & $48 \cdot 13$ & 45.69 & $53 \cdot 88$ & $5 \mathrm{I} \cdot \mathrm{IS}$ & $49 \cdot 92$ & $47 \cdot 39$ \\
\hline 12 & $68 \cdot 78$ & 33.22 & $22 \cdot 85$ & 43.04 & $29 \cdot 62$ & $37 \cdot 90$ & 26.07 \\
\hline 13 & 105.97 & 49.44 & 52.39 & $44 \cdot 14$ & $46 \cdot 77$ & $45 \cdot 82$ & $48 \cdot 56$ \\
\hline 14 & 120.44 & $5 I \cdot 09$ & 61.53 & $52 \cdot 18$ & 62.85 & 53.37 & $64 \cdot 28$ \\
\hline 15 & 119.99 & $52 \cdot 29$ & $62 \cdot 22$ & 56.50 & $67 \cdot 23$ & 53.00 & 63.07 \\
\hline 16 & 106.92 & 44.21 & $47 \cdot 27$ & 50.55 & 54.05 & $50 \cdot 66$ & $54 \cdot 17$ \\
\hline 17 & $100 \cdot 37$ & $44: 36$ & 44.52 & 50.85 & 51.04 & $48 \cdot 13$ & $3^{8 \cdot 31}$ \\
\hline 18 & 119.59 & $47 \cdot 35$ & $56 \cdot 62$ & 44.50 & 53.22 & $48 \cdot 44$ & 57.93 \\
\hline 19 & $132 \cdot 72$ & $52 \cdot 18$ & $69 \cdot 25$ & $56 \cdot 34$ & $74 \cdot 82$ & $56 \cdot 30$ & 74.72 \\
\hline Mean & 97.55 & $44 \cdot 70$ & $45 \cdot 63$ & $48 \cdot 60$ & 48.07 & 47.46 & 47.09 \\
\hline SD & 19.81 & 6.02 & 14.50 & $5 \cdot 3 I$ & I 3.88 & $5 \cdot 13$ & 13.85 \\
\hline
\end{tabular}

nineteen patients in Table 3 enables us to ascribe a fraction of the weight loss to fat-free tissue and the remainder to fat.

There are therefore five ways in which the fat loss of these nineteen women can be calculated: the average fat loss calculated from energy balance is 2.77 (SD $0.7 \mathrm{I}$ ) kg, from $\mathrm{N}$ balance 2.69 (SD I.23) kg, from the change in density 2.88 (SD 2.28 ) $\mathrm{kg}$, from the change in total body water 2.37 (SD 2.38 ) kg, and from the change in total body $\mathrm{K} 2.90$ (SD 3.54 ) kg. If it is assumed that the energy balance calculation of fat loss is correct, then the average difference of the other methods, calculated by the method of paired differences (Bailey, 1974), is 0.08 (SEM 0.26 ) $\mathrm{kg}$ for $\mathrm{N}$ balance 0.05 (SEM 0.53 ) $\mathrm{kg}$ for density, 0.40 (SEM 0.52) kg for water, and 0.13 (SEM 0.82) $\mathrm{kg}$ for the calculation based on measurements of $\mathrm{K}$. These differences are not statistically significant $(P>0 \cdot 10)$, which indicates that the assumptions used to calculate the change in body composition from measurements of $\mathrm{N}$ balance, density, water and $\mathrm{K}$ are reasonably accurate, and these methods will give similar answers when applied to groups of subjects.

\section{DISCUSSION}

The five methods for estimating fat loss (Table 3) were applied to nineteen patients, and each method gives a slightly different mean result, and a standard deviation about that mean. It would be possible to alter the assumed $\mathrm{N}$, density, water and $\mathrm{K}$ content of fat-free tissue so as to make the mean values identical for all methods in this series of patients, but this manoeuvre would not affect the relative ability of each method to measure change in fat content in an individual, since no adjustment of the constants in the calculation will affect the scatter of results due to error. 


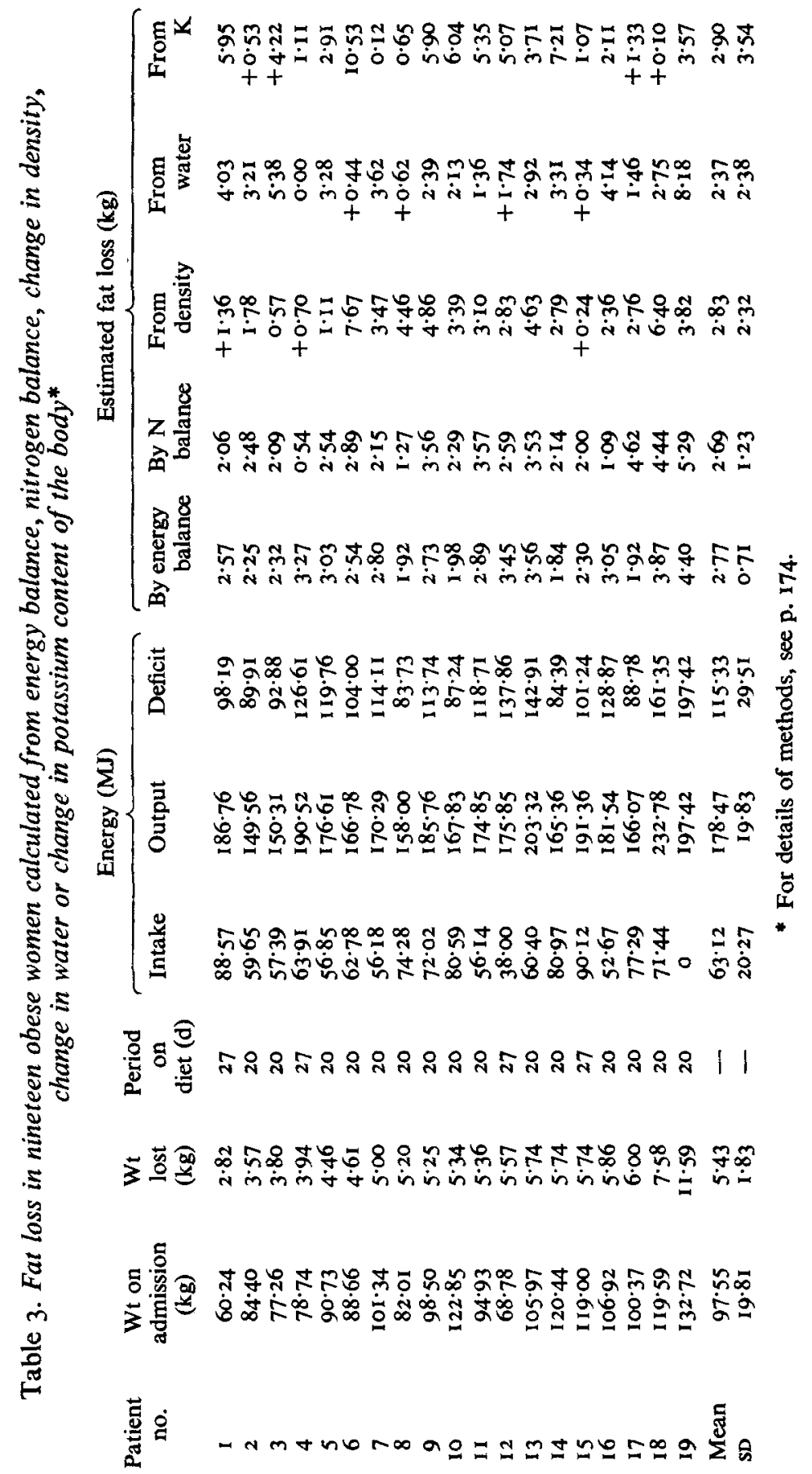


The fat loss estimated from energy balance for these nineteen patients was $2 \cdot 77 \pm 0.7 \mathrm{I} \mathrm{g}$ : the standard deviation of $0.7 \mathrm{I} \mathrm{kg}$ has three components. First, there is the true interindividual variation in fat loss among the nineteen patients, second is the error in measuring energy balance, and third is the error in assuming that each patient must lose either fat or non-fat tissue with an assumed energy value for each of these two types of tissue. Similarly, for each of the other methods the standard deviation is made up from similar components, the true subject inter-individual variation, the measurement errors, and the errors inherent in the constants used to calculate fat loss from these constants. Since the standard deviation by energy balance was $0.7 \mathrm{I} \mathrm{kg}$ this sets an upper limit to the magnitude of the interindividual variation which is common to all the methods: if we assume that the energy balance technique had zero error in measurement or assumed constants the total variation of $0.7 \mathrm{I} \mathrm{kg}$ is ascribed to individual variation in true fat loss.

The objective of this paper is to determine the accuracy with which change in fat content in an individual can be estimated from serial measurements in body density, and to compare this method with methods based on measurements of water or $\mathrm{K}$. The errors in the various methods will sometimes increase, and sometimes decrease, the apparent inter-individual variation, but the total variation will be the square root of the sum of the squares of true individual variation and the apparent variation caused by the two types of 'error' mentioned previously.

The calculation of 'error' in the various methods, assuming no error in the energy balance method, is set out in Table 4. The standard deviation due to the total 'error' is $\mathrm{I} \cdot 00,2 \cdot \mathrm{I} 7,2 \cdot 27$ and $3.47 \mathrm{~kg}$ fat for $\mathrm{N}$ balance, density, water and $\mathrm{K}$ respectively. This is considerably more than would be expected from an estimate of 'error' based on the replication of measurements in a single subject. For example replicate measurements of density yield values which agree within $0.30 \mathrm{~kg}$ fat (see Table I), replicate measurements of water in a phantom agree within $0.5 \%$, which is roughly equivalent to $0.3 \mathrm{~kg}$ fat (Halliday \& Miller, 1977), and replicate measurements of $\mathrm{K}$ agree to approximately $100 \mathrm{mmol}$, which is equivalent to approximately $\mathrm{I} \cdot 5 \mathrm{~kg}$ fat (Smith et al. 1979). It appears, therefore, that less than half the error in estimating change of fat content by any of these methods arises from measurement error, but the major contribution to the total error lies with the assumptions inherent in the calculations.

There is strong external evidence to support this conclusion. For example the observed water content of the fat-free body of six adult cadavers was 728, 775, 733, 674, 730 and $704 \mathrm{~g} / \mathrm{kg}$, giving an average value of $725 \mathrm{~g} / \mathrm{kg}$ which agrees well with the assumed value of $730 \mathrm{~g} / \mathrm{kg}$ for the group, but values for individuals in this group vary considerably. Similarly the measured $\mathrm{K}$ content of these six fat-free cadavers ranged from $66 \cdot 6$ to $73 \cdot 0 \mathrm{mmol} / \mathrm{kg}$. When serial measurements are made to estimate change in fat content a still more tenuous assumption is needed, namely that the density, $\mathrm{N}$, water or $\mathrm{K}$ content of the fat-free tissue lost is similar to that of the fat-free tissue which remains. This is improbable, since there is no reason why the contribution of, say, skin, bone, brain, liver and muscle to the tissue lost should resemble the proportions of these organs in the body which remains, and these organs differ widely in their N, water and K content (Garrow, 1978).

It appears from the results quoted above that change in density provides a more reliable estimate of change in body fat than can be obtained from change in water or $\mathrm{K}$ content. However, all these methods sometimes give erratic results, so care is needed when interpreting results on individuals or small groups. Table 5 shows the number of patients in whom the estimated fat loss from $\mathrm{N}$ balance, density, water or $\mathrm{K}$ agreed with that obtained from the energy balance calculation. If a limit of $I .0 \mathrm{~kg}$ difference between methods is allowed there 
Table 4. Estimated error in measurement of fat loss in obese women by nitrogen balance, density, water or potassium measurements*

$\begin{array}{lcccc}\text { Method } & \begin{array}{c}\text { Observed } \\ \text { SD (kg) }\end{array} & \text { Variance } & \begin{array}{c}\text { Variance due } \\ \text { to error }\end{array} & \begin{array}{c}\text { SD on } \\ \text { measurement } \\ \text { due to error } \\ (\mathbf{k g})\end{array} \\ \text { Energy balance } & 0.71 & 0.50 & - & - \\ \text { N balance } & 1.23 & 1.51 & 1.01 & 1.00 \\ \text { Density } & 2.28 & 5.20 & 4.70 & 2.17 \\ \text { Water } & 2.38 & 5.66 & 5.16 & 2.27 \\ \text { K } & 3.54 & 12.53 & 12.03 & 3.47 \\ & \text { * For details of methods, see p. 174. } & \end{array}$

Table 5. Agreement between estimates of fat loss based on measurement of nitrogen balance, density, water or potassium, and that based on measurement of energy balance, in a series of nineteen obese women

$\begin{array}{ccccc}\begin{array}{c}\text { Deviation from } \\ \text { energy balance } \\ (\mathrm{kg})\end{array} & \begin{array}{c}\text { N } \\ \text { balance }\end{array} & \text { Density } & \text { Water } & \text { K } \\ 0-1 & 16 & 8 & 7 & \\ 0-2 & 17 & 12 & 12 & 4 \\ 0-3 & 19 & 16 & 15 & 7 \\ 0-4 & - & 18 & 18 & 15 \\ 0-5 & - & 18 & 18 & 16 \\ 0-6 & - & 19 & 19 & 17 \\ 0-7 & - & - & - & 18 \\ 0-8 & - & - & - & 19\end{array}$

is agreement for sixteen, eight, seven or four patients out of the total series of nineteen. If a tolerance of $3 \mathrm{~kg}$ is allowed all the estimates based on $\mathrm{N}$ balance agree, and sixteen, fifteen and eleven by density, water and $\mathrm{K}$ respectively. The largest deviations between energy balance and the other methods were $2.73 \mathrm{~kg}$ for $\mathrm{N}$ balance (patient no. 4 ), $5.13 \mathrm{~kg}$ for density (patient no. 6), $5.19 \mathrm{~kg}$ for water (patient no. 12 ), and $7.99 \mathrm{~kg}$ for $\mathrm{K}$ (patient no. 6). In these extreme cases of error it is probable that the main cause was not inaccurate measurement technique, but a change in body composition which did not conform to the assumed composition of fat-free tissue.

The authors are grateful to D. G. Altman for advice on the statistical analysis of these results, to the nursing and dietetic staff on Cavendish Ward for their supervision of the patients, and to H.S. Wolff and the Division of Bioengineering for designing and building the plethysmograph.

\section{REFERENCES}

Allen, T. H., Krzywicki, H. J. \& Roberts, J. E. (1959). J. appl. Physiol. 14, I005.

Bailey, N. T. J. (1974). Statistical Methods in Biology, p. 43. London: English Universities Press.

Behnke, A. R., Feen, B. G. \& Welham, W. C. (1942). J. Am. med. Ass. I18, 495.

Department of Health and Social Security/Medical Research Council Study Group (1976). In Research on Obesity, p. 94 [W. P. T. James, editor]. London: H.M. Stationery Office.

Durnin, J. V. G. A. \& Womersley, J. (1974). Br. J. Nutr. 32, 77.

Garrow, J. S. (1978). In Energy Balance and Obesity in Man, 2nd ed., p. 335. Amsterdam: Elsevier/North Holland Publishing Co.

Garrow, J. S., Durrant, M. L., Mann, S., Stalley, S. F. \& Warwick, P. M. (1978). Int. J. Obesity 2, 44 I. Halliday, D. \& Miller, A. G. (1977). Biomed. Mass Spect. 4, 82. 
Hytten, F. E., Taylor, K. \& Taggart, N. (1966). Clin. Sci. 31, 111 .

Irsigler, K. Heitkamp, H., Schlick, W. \& Schmid, P. (1975). In Regulation of Energy Balance in Man, p. 72 [E. Jequier, editor]. Geneva: Editions Medecine et Hygiene.

Keys, A. \& Brozek, K. (1953). Physiol. Rev. 33, 245.

Lesser, G. T., Deutsch, S. \& Markofsky, J. (1971). Metabolism 20, 792.

Siri, W. E. (1961). In Techniques for Measuring Body Composition, p. 223 [J. Brozek and A. Henschel, editors]. Washington, DC: National Academy of Science.

Smith, T., Hesp, R. \& MacKenzie, J. (1979). Phys, med. Biol. 24, 17 I.

Wang, J. \& Pierson, R. N. (1976). J. Nutr. I06, 1687.

Womersley, J., Durnin, J. V. G. A., Boddy, K. \& Mahaffy, M. (1976). J. appl. Physiol. 4r, 223. 